\title{
DISTRIBUTION OF IRON (II) BETWEEN BUFFERED AQUEOUS SOLUTIONS AND CHLOROFORM SOLUTION OF N,N'-ETHYLENEBIS(4- BUTANOYL-2,4-DIHYDRO-5-METHYL-2-PHENYL-3H-PYRAZOL-3- ONEIMINE)
}

\author{
J. Godwin ${ }^{1^{*}}$, U. J. Chukwu ${ }^{2}$ and T. D. Gad $^{3}$ \\ ${ }^{1}$ Department of Chemical Sciences, Niger Delta University Wilberforce Island, PMB 71, Bayelsa State, \\ Nigeria. \\ Godwinj2012@gmail.com \\ ${ }^{2}$ Department of Pure and Industrial Chemistry, University of Port Harcourt, PMB, 5323, Port Harcourt, Rivers \\ State, Nigeria. \\ lydiuche@yahoo.com \\ ${ }^{3}$ Department of Chemical Sciences, Niger Delta University Wilberforce Island, PMB 71, Bayelsa State, \\ Nigeria. \\ dorathygad@gmail.com
}

\begin{abstract}
The distribution of $\mathrm{Fe}$ (II) between buffered aqueous solution and chloroform solution of N,N'-Ethylenebis(4-butanoyl-2-4dihydro-5-methyl-2-phenyl-3H-pyrazol-3-oneimine $)\left(\mathrm{H}_{2} \mathrm{BuEtP}\right)$ was investigated. The effect of 4-butanoyl-2-4-dihydro-5methyl-2-phenyl-3H-pyrazol-3-one(HBuP) in the distribution was also studied. Fe(II) concentration in aqueous raffinate was determined colorimetrically and distribution ratios and percentage extractions calculated by difference from Fe(II) in aqueous phase before and after equilibrations. The optimal $\mathrm{pH}$ for $\mathrm{Fe}(\mathrm{II})$ distribution slightly lowered to 8.00 in mixed ligands $\left(\mathrm{H}_{2} \mathrm{BuEtP} / \mathrm{HBuP}\right)$ organic phase from 8.25 in ligand $\left(\mathrm{H}_{2} \mathrm{BuEtP}\right)$ alone organic phase. The pH range at which quantitative extraction of $\mathrm{Fe}$ (II) from aqueous buffered solution into both type of organic phases used for the study was very narrow. The extraction parameters; $\mathrm{pH}_{1 / 2}$, log $\mathrm{D}$ from extraction plots, and log $\mathrm{K}_{\mathrm{ex}}$ calculated using extraction equations derived from slope analysis showed that the values in both type of organic phases were very close even though mixed ligands $\left(\mathrm{H}_{2} \mathrm{BuEtP} / \mathrm{HBuP}\right)$ organic phase values were slightly higher and better. Slope analysis also indicated that the $\mathrm{Fe}(\mathrm{II})$ complexes extracted into both organic phases were $\mathrm{Fe}(\mathrm{BuEtP})_{0}$ and $\mathrm{Fe}(\mathrm{HBuEtP})(\mathrm{BuP})_{\circ}$ respectively.
\end{abstract}

\section{Indexing terms/Keywords}

Aqueous media; buffered; distribution; Fe(II); N,N'-ethylenebis(4-butanoyl-2,4-dihydro-5-methyl-2-phenyl-3H-pyrazol-3oneimine); organic phases.

\section{Academic Discipline And Sub-Disciplines}

Chemistry; Analytical chemistry

\section{SUBJECT CLASSIFICATION}

Applied Chemistry; Solvent Extraction

\section{TYPE (METHOD/APPROACH)}

Many organic phases has been extentisvely studied for the extraction and separation of various metal ions from aqueous media using solvent-solvent extraction technique. Results from these studies have been utilized in deisgning methods for treating metals from industrial effluents and recently in dating of materials through extraction and separation of radioactive nuclides that have a parent and daughter relationship.

\section{Council for Innovative Research}

Peer Review Research Publishing System

Journal: Journal of Advances in Chemistry

Vol. 8, No. 2

editor@cirjac.com

www.ciriac.com, member.cirworld.com 


\section{INTRODUCTION}

Solvent extraction of metal ions using Schiff bases has generated lots of interesting results over the years. The successes recorded in these studies have been utilized in the synthesis of a wide range of metal complexes with varying properties; trivalent Samarium, Europium and Gadolinium complexes of tridentate salicylidene hydrazone derivatives of 4 acylpyrazolone $-5^{1}$ have shown that their solid complexes have fluorescence properties and the thiosemicarbazone ${ }^{2}$ Schiff base derivatives exhibited biochemical ${ }^{3}$, photo chromic ${ }^{2}$ and acid chromic properties due to tautomerism in their molecular structures. There are also reports of promising antitumor, antipyretic and anti-inflammatory activity of Schiff bases ${ }^{3,4}$. These extractions have also been successfully applied in separation of metal ions in aqueous solutions owing to varying degree of extraction of metal at different $\mathrm{pH}$, in the presence of mineral acids, common anions and auxiliary complex agents ${ }^{5,6}$.

In the quest to discover more efficient extractant with a wide pH range of extraction of metal ions, new Schiff bases N.N'Ethylenebis(1-phenyl-3-methyl-4-acylpyrazoloneimine) and its derivatives $\quad$ N,N'-Ethylenebis(4-butanoyl-2,4-dihydro5-methyl-2-phenyl-3H-pyrazol-3-oneimine ( $\left.\mathrm{H}_{2} B \mathrm{BuEtP}\right), \quad$ N.N'-Bis(1-phenyl-3-methyl-4-acetylpyrazoloneimine)-1,2propane $\left(\mathrm{H}_{2} \mathrm{ADPP}\right)$ and N.N'-Ethylenebis(1-phenyl-3-methyl-4-propionylpyrazolohneimine) ( $\left.\mathrm{H}_{2} P r E t P\right)$ have been successfully synthesized, characterized using ultraviolet, infrared, ${ }^{\mathrm{H}}$ and ${ }^{13} \mathrm{C} \mathrm{NMR}^{7}$ and have also shown excellent extraction abilities for $\mathrm{Ni}(\mathrm{II})^{8}, \mathrm{~Pb}(\mathrm{II})^{9}$ and $\mathrm{U}(\mathrm{VI})^{10,11}$.

In continuation of our evaluation of metal ions extraction with these synthesized 4-acylbis(1-phenyl-3-methy pyrazoloneimines), we report the distribution of $\mathrm{Fe}(\mathrm{II})$ from aqueous solution into chloroform solution of $N, N^{\prime}$ Ethylenebis(4-butanoyl-2,4-dihydro-5-methyl-2-phenyl-3H-pyrazol-3-oneimine $\left(\mathrm{H}_{2} \mathrm{BuEtP}\right)$ organic phase. The effect of 4 butanoyl-2,4-dihydro-5-methyl-2-phenyl-3H-pyrazol-3-one (HBuP) in the distribution of Fe(II) between the two phases was also investigated. The research is aimed at determining the potentials of $N, N^{\prime}$-Ethylenebis(4-butanoyl-2,4-dihydro-5methyl-2-phenyl-3H-pyrazol-3-oneimine $\left(\mathrm{H}_{2} \mathrm{BuEtP}\right)$ in the extraction of $\mathrm{Fe}(\mathrm{II})$ from aqueous solution with the objective of determining the $\mathrm{pH}$ range at which quantitative extraction of $\mathrm{Fe}(\mathrm{II})$ can be achieved.

\section{MATERIALS AND METHOD}

All reagents and chemicals used in the study were all analytical grade from BDH and Aldrich. 4-butanoyl-2,4-dihydro-5methyl-2-phenyl-3H-pyrazol-3-one (HBuP)(figure. 1) and $N, N^{\prime \prime}$-Ethylenebis(4-butanoyl-2,4-dihydro-5-methyl-2-phenyl-3Hpyrazol-3-oneimine) ( $\mathrm{H}_{2} \mathrm{BuEtP}$ ) (figure. 2) were synthesised by method described elsewhere ${ }^{7}$. The ligands were recrystallized from aqueous ethanol and its purity established by elemental analysis for $\mathrm{C}, \mathrm{H}$ and $\mathrm{N}$. The synthesised ligand $N, N^{\prime}$-Ethylenebis(4-butanoyl-2,4-dihydro-5-methyl-2-phenyl-3H-pyrazol-3-oneimine) melting point was determined with a melting point apparatus to be $234^{\circ} \mathrm{C}$. Measurement of IR and NMR spectral data were done at the Institut fur Anorganische Chemie, Technische Universitat Dresden, Germany. Stock solutions of $0.05 \mathrm{M} \mathrm{H}_{2} \mathrm{BuEtP}$ and $0.05 \mathrm{M} 4$ butanoyl-2,4-dihydro-5-methyl-2-phenyl-3H-pyrazol-3-one (HBuP) were prepared by dissolving appropriate mass of the ligands in $\mathrm{CHCl}_{3}$. A $2000 \mathrm{mgL}^{-1}$ stock solution of $\mathrm{Fe}^{2+}$ was prepared by dissolving $1.404 \mathrm{~g}$ of Ferrous Ammonium Sulphate $\left[\left(\mathrm{NH}_{4}\right)_{2} \mathrm{SO}_{4} . \mathrm{FeSO}_{4} 6 \mathrm{H}_{2} \mathrm{O}\right]$ in $100 \mathrm{ml}$ volumetric flask containing $2 \mathrm{ml}$ of sulphuric $\left[\mathrm{H}_{2} \mathrm{SO}_{4}\right]$ made up to the $100 \mathrm{ml}$ mark with deionized water. Buffer solutions were prepared with $0.1 \mathrm{M} \mathrm{HCl} / 0.1 \mathrm{M} \mathrm{NaCl}(\mathrm{pH} 1.0-3.0), 0.1 \mathrm{M}$ acetic acid/0.1 M NaCl $(\mathrm{pH} 3.0-3.5), 0.1 \mathrm{M}$ acetic acid/0.1 M Na-acetate $(\mathrm{pH} 3.6-5.6)$ and $0.1 \mathrm{M} \mathrm{KH}_{2} \mathrm{PO}_{4} / 0.1 \mathrm{M} \mathrm{NaOH}(\mathrm{pH} 5.7-9.0)$. The actual $\mathrm{pH}$ of solutions were determined with a Labtech Digital $\mathrm{pH}$ meter.

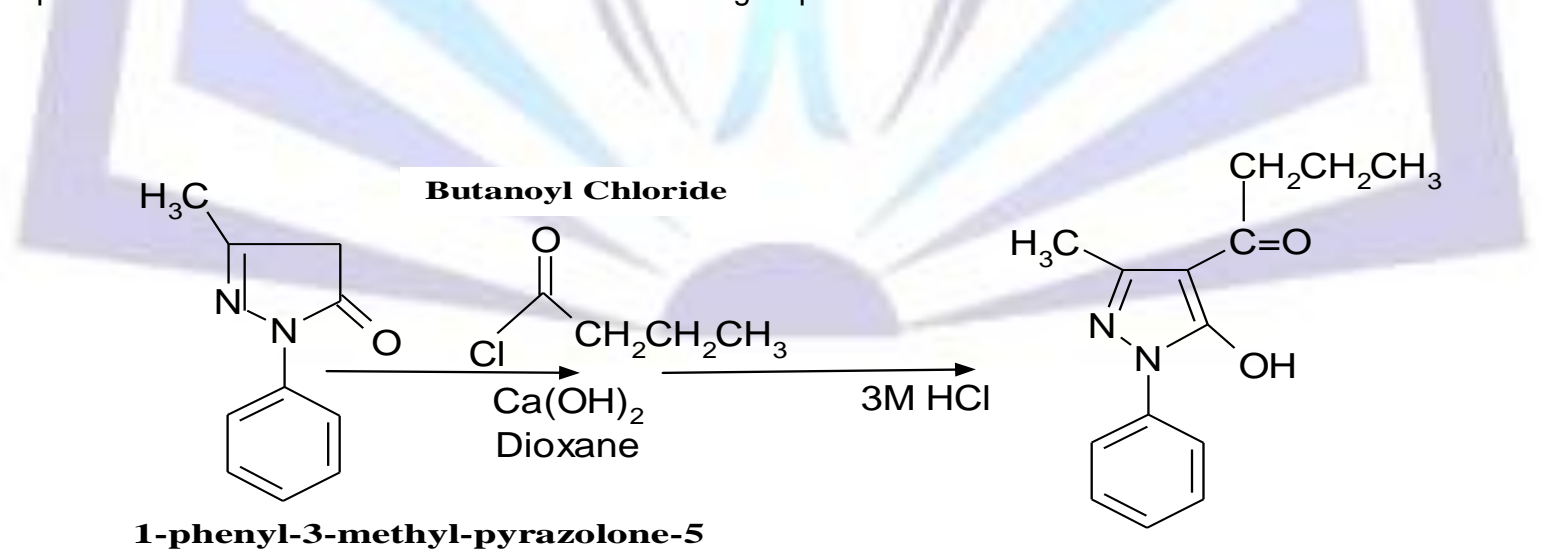

Fig 1: Reaction for the synthesis of 4-butanoyl-2,4-dihydro-5-methyl-2-phenyl-3H-pyrazol-3-one (HBuP) 


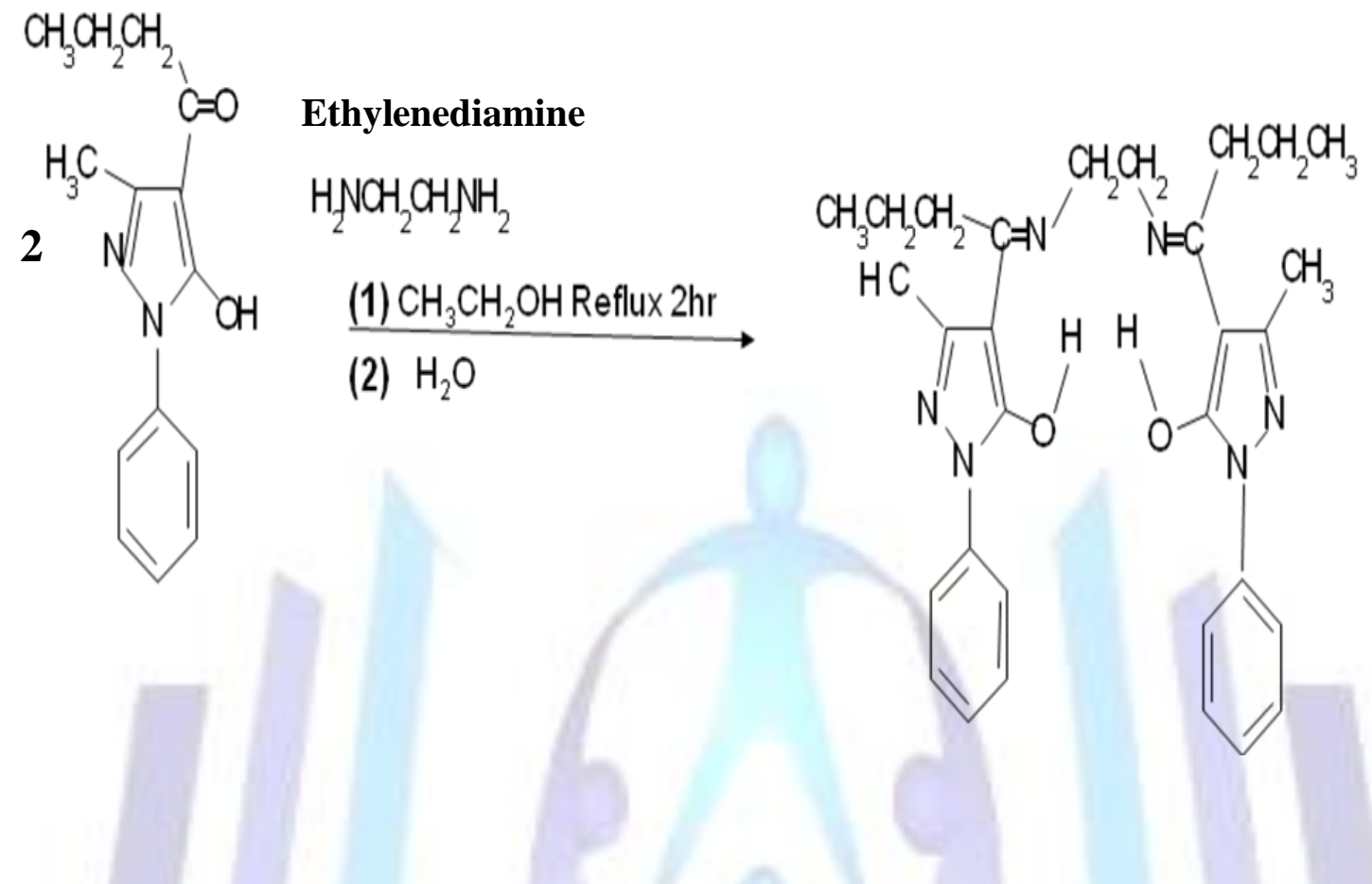

Fig 2: Reaction for the synthesis of N, N'-Ethylenebis(4-butanoyl-2,4-dihydro-5-methyl-2-phenyl-3H-pyrazol3-oneimine) ( $\left.\mathrm{H}_{2} \mathrm{BuEtP}\right)$

\subsection{Extraction Procedure}

$10 \mathrm{~mL}$ corked extraction bottles containing $2 \mathrm{~mL}$ aliquot of buffered solutions containing $200 \mathrm{mgL}^{-1}$ of $\mathrm{F}$ (II) ions were prepared. Two millilitre $(2 \mathrm{~mL})$ solutions of $0.05 \mathrm{M}$ concentration of $\mathrm{H}_{2} \mathrm{BuEtP}$ or $0.05 \mathrm{M} \mathrm{H}_{2} \mathrm{BuEtP}: 0.05 \mathrm{M} \mathrm{HBuP}$ (9:1 ratio by volume) in chloroform was pipetted into the aqueous phases in the extraction containers. The immiscible phases were shaken mechanically for 40 minutes at a room temperature of $30{ }^{\circ} \mathrm{C}$. A shaking time of 40 minutes was found suitable enough for equilibration. The two phases were allowed to settle and separated.

The concentration of $\mathrm{Fe}(\mathrm{II})$ in the aqueous phase was determined colorimetrically with a UV spectrophotometer (Spectronic 20 Genesys) at wavelength of $520 \mathrm{~nm}^{5}$. The colour development for Iron(II) determination was by addition of $0.1 \mathrm{ml}$ of hydroxylamine hydrochloric acid, $0.5 \mathrm{ml}$ of 1,10 -phenathroline and $0.5 \mathrm{ml}$ of sodium acetate. Fe(II) ion concentration extracted into the organic phase was determined from the difference between the concentration of Fe(II) ion in aqueous phase before and after the extraction. Distribution ratio $D$ was calculated as the ratio of metal ion concentration in the organic phase $\left(C_{o}\right)$ to that in the aqueous phase $(C)$. Thus $\mathrm{D}=C_{o} / C$.

\section{RESULTS AND DISCUSSION}

The addition of $\mathrm{H}_{2} \mathrm{BuEtP}$ organic phase to the aqueous phase containing $\mathrm{Fe}(\mathrm{II})$ at $\mathrm{pH}$ range of $8.00-8.25$ resulted in the immediate formation of a purple coloured solution. This was not observed at other $\mathrm{pH}$ and indicates that at these $8.00-$ $8.25 \mathrm{pH}$ range, coloured Fe complex species formed. The coloured Fe complex with $\mathrm{H}_{2} \mathrm{BuEtP}$ can be evaluated for use as a colorimetric reagent for $\mathrm{Fe}$ analysis. The presence of ligand $\mathrm{H}_{2} \mathrm{BuEtP}$ alone, plots of log $\mathrm{D}$ against pH shown in figure 3 had a slope of 2, indicating that two hydrogen ions where displaced during the extraction reaction. Figure 4, showing plots of log $D$ against $\log \left[\mathrm{H}_{2} \mathrm{BuEtP}\right]$ had a slope of 1 and Figure 6 plots of log D against log Fe(II) had slope of 0 . These results indicates that 1 mole of the ligand $\mathrm{H}_{2} \mathrm{BuEtP}$, reacted with 1 mole of $\mathrm{Fe}(\mathrm{II})$ during the extraction reaction. 


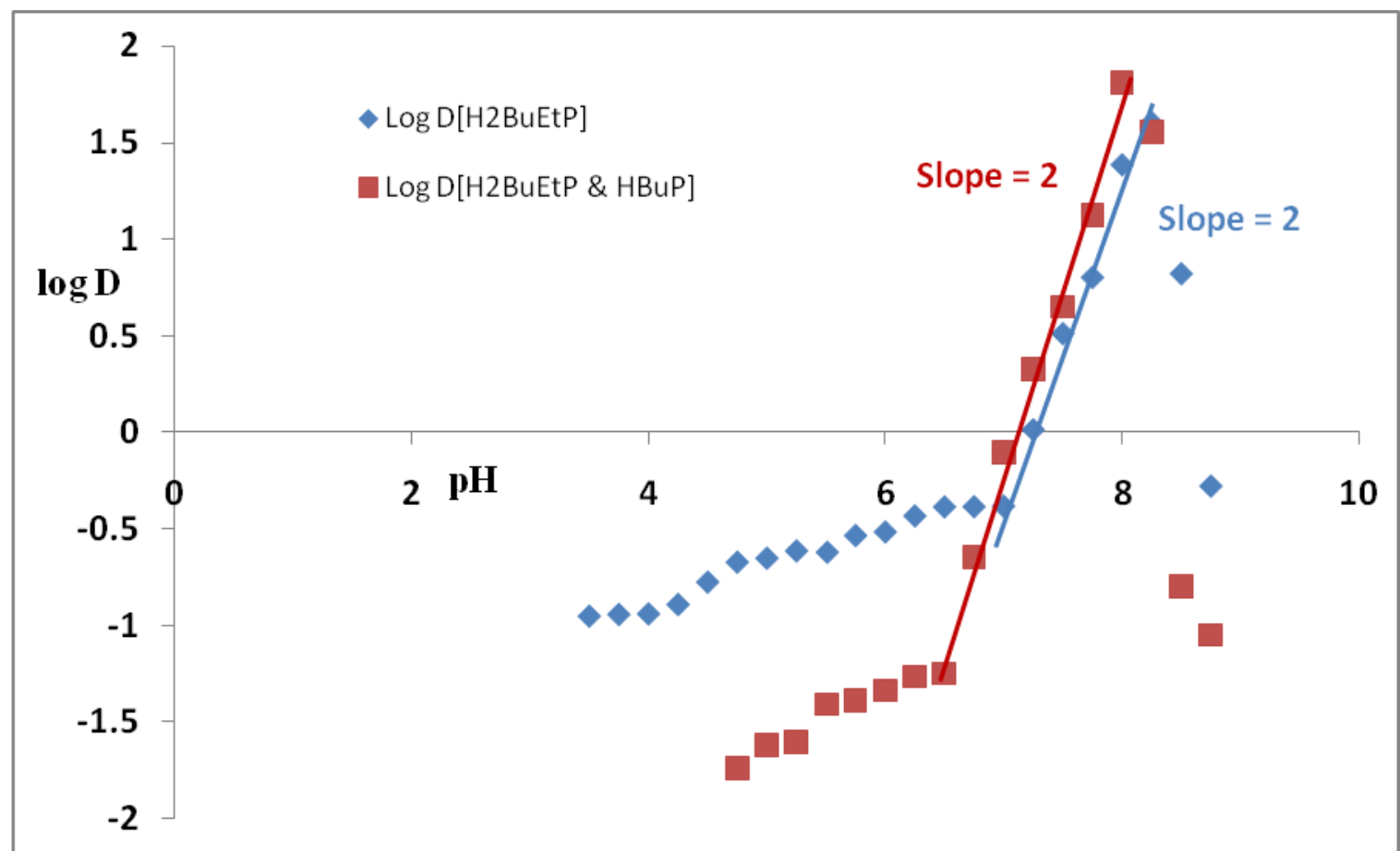

Fig 3: Plots of extraction of $3.58 \times 10^{-3} \mathrm{M}(200 \mathrm{mg} / \mathrm{L}) \mathrm{Fe}$ (II) from buffer solutions into chloroform solution of $0.05 \mathrm{M}$ $\mathrm{H}_{2} \mathrm{BuEtP}$ and $0.05 \mathrm{M} \mathrm{H}_{2} \mathrm{BuEtP} \& 0.05 \mathrm{M} \mathrm{HBuP(9:1)}$ volume ratio

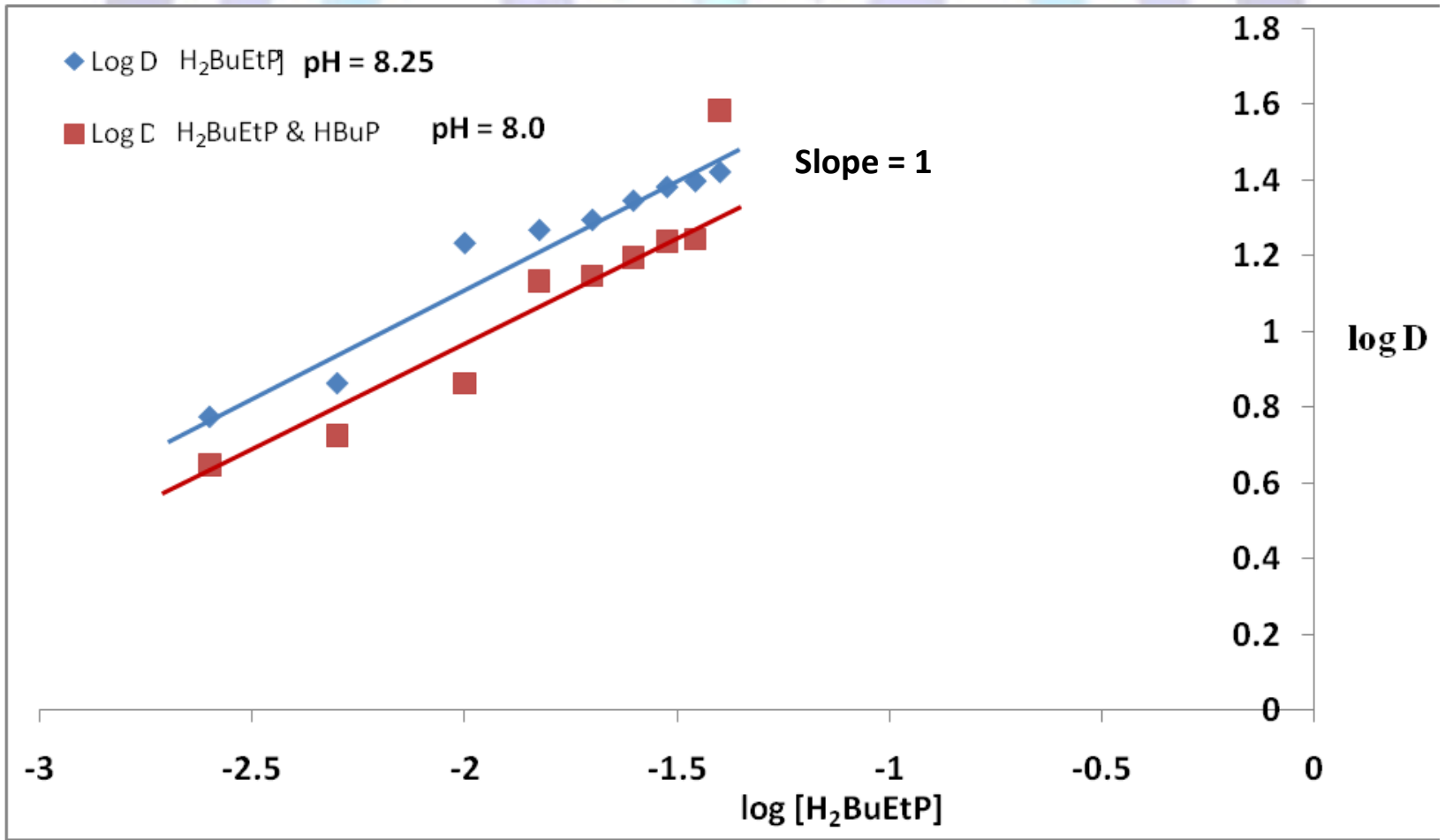

Fig 4: $\mathrm{Log}$ D-log [ $\left.\mathrm{H}_{2} \mathrm{BuEtP}\right]$ plot of extraction of $3.58 \times 10^{-3} \mathrm{M}(200 \mathrm{mg} / \mathrm{L})$ of $\mathrm{Fe}(\mathrm{II})$ from buffered solutions at pH $8.25\left[\mathrm{H}_{2} \mathrm{BuEtP}\right]$ and $\mathrm{pH} 8.00\left[\mathrm{H}_{2}\right.$ BuEtP and HBuP] into chloroform solutions of varied ligand $\left[\mathrm{H}_{2} \mathrm{BuEtP}\right]$ 


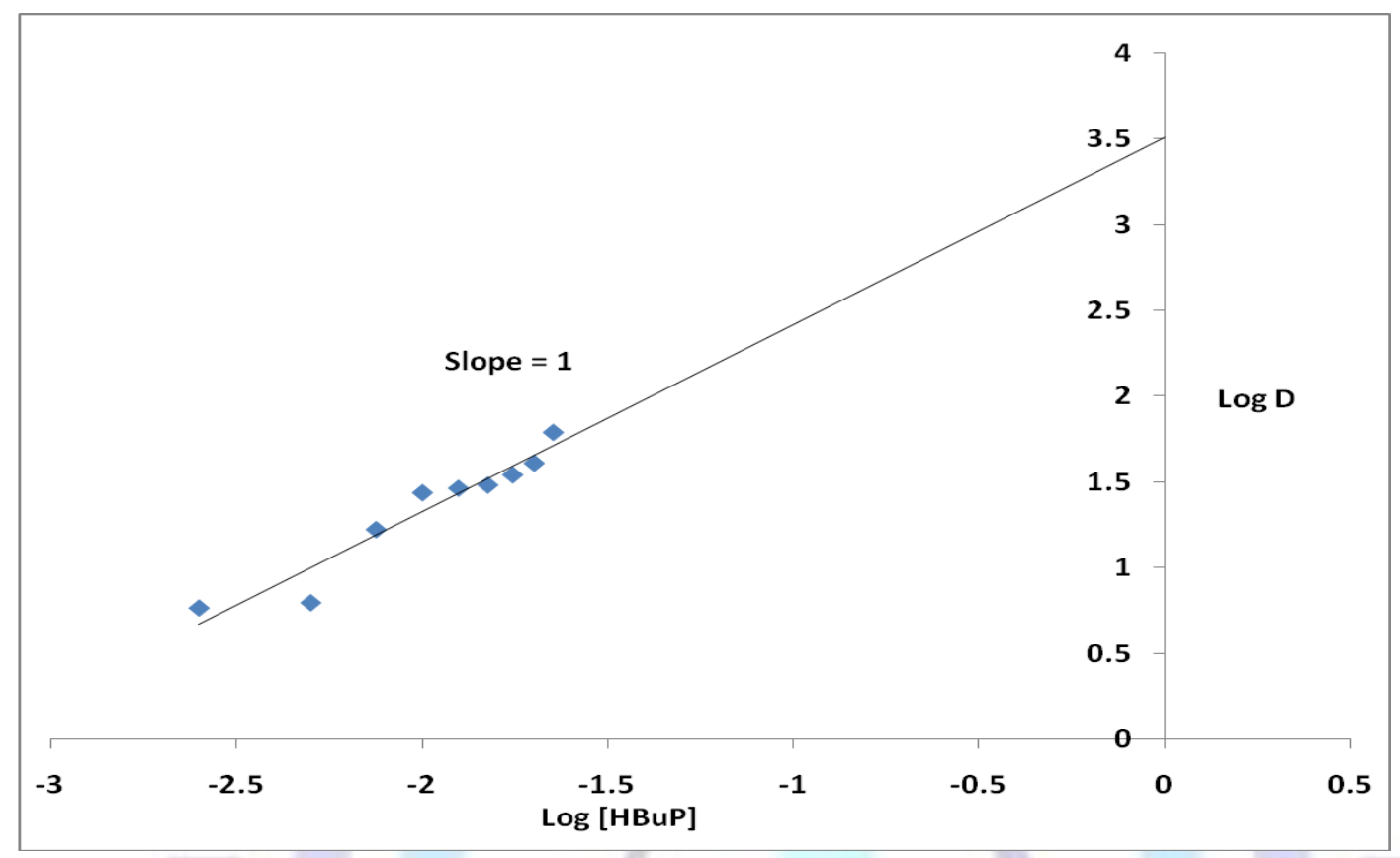

Fig 5: Log D-log [Ligand] plot of extraction of $200 \mathrm{mg} / \mathrm{L}$ of $\mathrm{Fe}$ (II) from buffered solutions at $\mathrm{pH} 8.0$ into chloroform solutions of [HBuP] varied while [ $\left.\mathrm{H}_{2} \mathrm{BuEtP}\right]$ was kept constant $\left(2.5 \times 10^{-2} \mathrm{M}\right)$

Log D [ $\mathbf{H}_{2}$ BuEtP] pH 8.25

$\log D\left[\mathbf{H}_{2}\right.$ BuEtP \& HBuP] pH 8.00
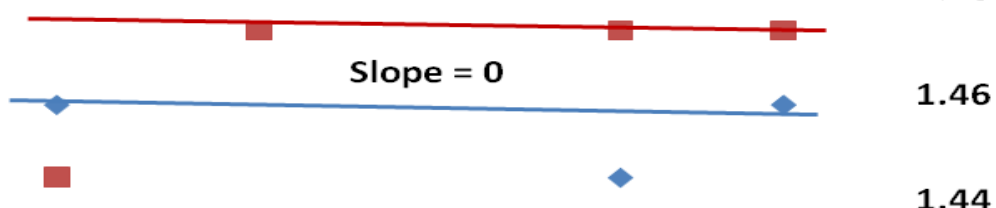

$-2.8$

$-2.75$

$-2.7$ $\log [\mathrm{Fe}(\mathrm{II})]$
1.44

1.42

1.4

1.38

1.5

1.48

1.46

$\log D$

$-2.55$

Fig 6: $\log \mathrm{D}-\log [\mathrm{Fe}(\mathrm{II})]$ plots of extraction of $\mathrm{Fe}(\mathrm{II})$ from buffer solutions at pH 8.25 and pH 8.00 into chloroform solutions of ligand $\mathrm{H}_{2} \mathrm{BuEtP}$ and $\mathrm{H}_{2} \mathrm{BuEtP} / \mathrm{HBuP}$ 
Extraction of $\mathrm{Fe}(\mathrm{II})$ from aqueous media into an organic solvent '(o)' containing a tetradentate ligand $\mathrm{H}_{2} \mathrm{BuEtP}$ from all the results in figures 3,4 , and 6 can be represented by the following equations:

$\mathrm{Fe}^{2+}+\mathrm{H}_{2} \mathrm{BuEtP}_{(\mathrm{o})} \rightleftharpoons \operatorname{Fe}\left(\mathrm{BuEtP}_{(\mathrm{o})}+2 \mathrm{H}^{+}\right.$

It shows that the reaction took place in the metal:ligand mole ratio of $1: 1$. Thus the extraction constant $\mathrm{K}_{\mathrm{ex} 1}$ can be represented by:

$$
\mathbf{K}_{\mathbf{e x 1}}=\frac{\left[F e(B u E t P)_{(o)}\right]\left[H^{+}\right]^{2}}{\left[F e^{2+}\right]\left[H_{2} B u E t P_{(o)}\right]}
$$

The distribution ratio $\left.D_{1}=\left[\mathrm{Fe}(\mathrm{BuEtP})_{(\mathrm{o})}\right] /\left[\mathrm{Fe}^{2+}\right]\right)$. Substitution into equation (2) gives:

$$
\log D_{1}=\log K_{e x 1}+\log \left[H_{2} B u E t P\right]+2 p H
$$

The partition coefficient $\left(K_{D 1}\right)$ of $F e(B u E t P)_{(0)}$ species is defined as $K_{D 1}=$

$\left[\mathrm{Fe}(\mathrm{BuEtP})_{(\circ)}\right] /[\mathrm{Fe}(\mathrm{BuEtP})]$ for which a value of $1.5 \pm 0.16$ was determined and the $\mathrm{pH}$ at which $50 \%$ extraction of a metal ion had occurred $\mathrm{pH}_{1 / 2}$ was found to be $7.24 \pm 0.10$ from the graph in figure 3 . Log $\mathrm{K}_{\mathrm{ex} 1}=-13.45 \pm 0.2$ was calculated using equation 3.

The extraction parameters were similar to those obtained for the extraction of $\mathrm{Ni}^{2+}$ ion with this ligand $\mathrm{H}_{2} \mathrm{BuEtP}$ as reported ${ }^{8}$ , indicating that similar mechanism might be involved in their extraction mechanisms. However, even though their $\mathrm{pH}_{1 / 2}$ values are close $\left(\mathrm{pH}_{1 / 2 \mathrm{Fe}}=7.24 \pm 0.10\right.$ and $\left.\mathrm{pH}_{1 / 2 \mathrm{Ni}}=7.14 \pm 0.10\right)$, comparing other extraction parameters with those of $\mathrm{Ni}^{2+}$ $\left(\right.$ Log $K_{\text {exNi }}=-12.39 \pm 0.64>\log K_{\text {exFe }}=-13.45 \pm 0.2$ and $\left.\log D_{\mathrm{Ni}}=1.89 \pm 0.05>\log D_{\mathrm{Fe}}=1.5 \pm 0.16\right)$ showed that $\mathrm{Ni}^{2+}$ distributed better than $\mathrm{Fe}^{2+}$ in the presence of this ligand $\mathrm{H}_{2} \mathrm{BuEtP}$. The optimal pH for the extraction of $\mathrm{Fe}(\mathrm{II})$ with the ligand $\mathrm{H}_{2} \mathrm{BuEtP}$ was 8.25 at which a $97.59 \%$ extraction of $\mathrm{Fe}(\mathrm{II})$ was achieved. However, it was observed that the $\mathrm{pH}$ range at which quantitative extraction occurred was very narrow $(7.5-8.5)$. It is noteworthy to state that the mechanism of extraction of $\mathrm{Fe}(\mathrm{II})$ and $\mathrm{Ni}(\mathrm{II})$ is different from that observed in the extraction of $\mathrm{Pb}(\mathrm{II})$ and $\mathrm{U}(\mathrm{VI})$ with the same ligand. In the distribution of $\mathrm{Pb}(\mathrm{II})$, it was observed that the extracted complex was proposed as ion pair tris complex species with a wide $\mathrm{pH}$ range $(5.9-8.0)$ at which quantitative extraction occurred ${ }^{9}$. In the case of $\mathrm{U}(\mathrm{VI})$, it was observed that anions from buffer reagents might have played a part in the formation and hydrophobicity of the extracted complex. The $\mathrm{pH}$ range at which quantitative extraction occurred was also wide $(5.5-8.25)^{10}$. The partition coefficient $\mathrm{K}_{\mathrm{D} 1}$ for $\mathrm{Fe}(\mathrm{II})$ compared with those gotten for the other three metal ions $\mathrm{Ni}(\mathrm{II}), \mathrm{Pb}(\mathrm{II})$ and $\mathrm{U}(\mathrm{VI})$ in similar studies with the same ligand $\mathrm{H}_{2} \mathrm{BuEtP}$ indicated that $\mathrm{U}(\mathrm{VI})$ was the least extracted into the oganic phase, while $\mathrm{Pb}(\mathrm{II})$ was the most extracted; $\log \mathrm{D}_{\mathrm{U}(\mathrm{VI})}=0.56 \pm 0.11<\mathrm{Log}$ $D_{\mathrm{Fe}(\mathrm{II})}=1.5 \pm 0.16<\log \mathrm{D}_{\mathrm{Ni}(\mathrm{II})}=1.89 \pm 0.05<\log \mathrm{D}_{\mathrm{Pb}(\mathrm{II})}=1.92 \pm 0.25$

Iron ions have been shown to form strong and weak bonds with nitrogen atom in ligands in their formation of complexes $^{12,13}$. Combining slope analysis results from figure 3, figure 4, figure 6 and the above information, the proposed structure of the extracted $\mathrm{Fe}(\mathrm{II})$ complex with the ligand $\mathrm{H}_{2} \mathrm{BuEtP}$ is shown in figure 7. 


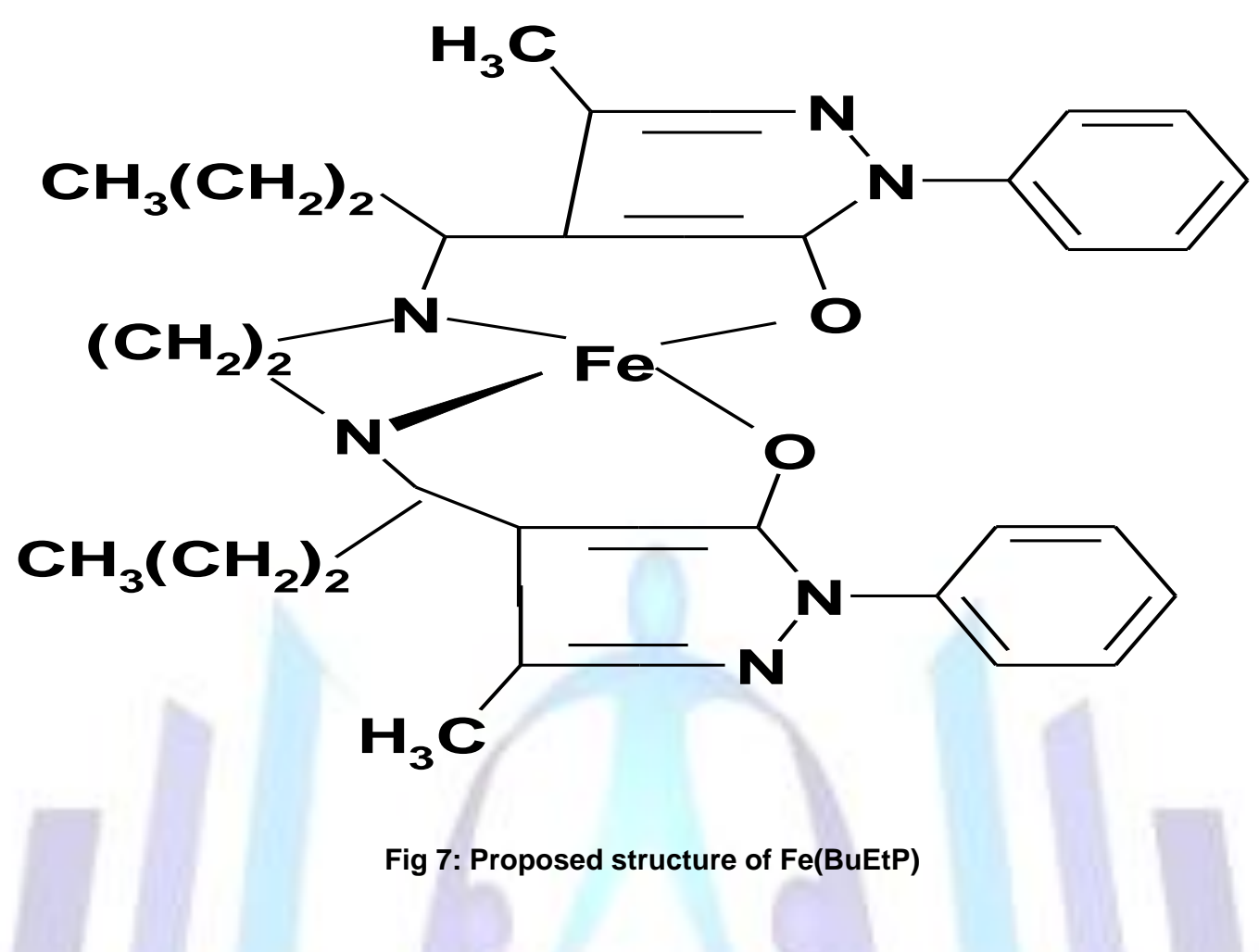

In the presence of HBuP and $\mathrm{H}_{2} \mathrm{BuEtP}$, results from figure 3 showed that two protons were also displaced during the reaction between $\mathrm{Fe}(\mathrm{II})$. Plots of Log $\mathrm{D}$ against $\log \left[\mathrm{H}_{2} \mathrm{BuEtP}\right]$ at fixed concentraion $\left(5 \times 10^{-3} \mathrm{M}\right)$ of $\mathrm{HBuP}$ (figure 4) had a slope of 1 , indicating that one mole of $\mathrm{H}_{2} \mathrm{BuEtP}$ was involved in the reaction. Also, plots of Log D against Log [HBuP] at fixed concentraion $2.5 \times 10^{-2} \mathrm{M}$ of the ligand $\mathrm{H}_{2} \mathrm{BuEtP}$ also had a slope of 1 (figure 5) also showing that one mole of HBuP was involved in the reaction. Log D against Log [Fe(II)] plots in figure 6 had a slope of zero, showing that one mole of $\mathrm{Fe}(\mathrm{II})$ also reacted with the ligands in the extraction process. Putting all this information together, we could represent the reaction for the extraction of $\mathrm{Fe}(\mathrm{II})$ from aqueous solutions into organic chloroform solution of ligands $\mathrm{H}_{2} \mathrm{BuEtP}$ and $\mathrm{HBuP}$ by equation 4

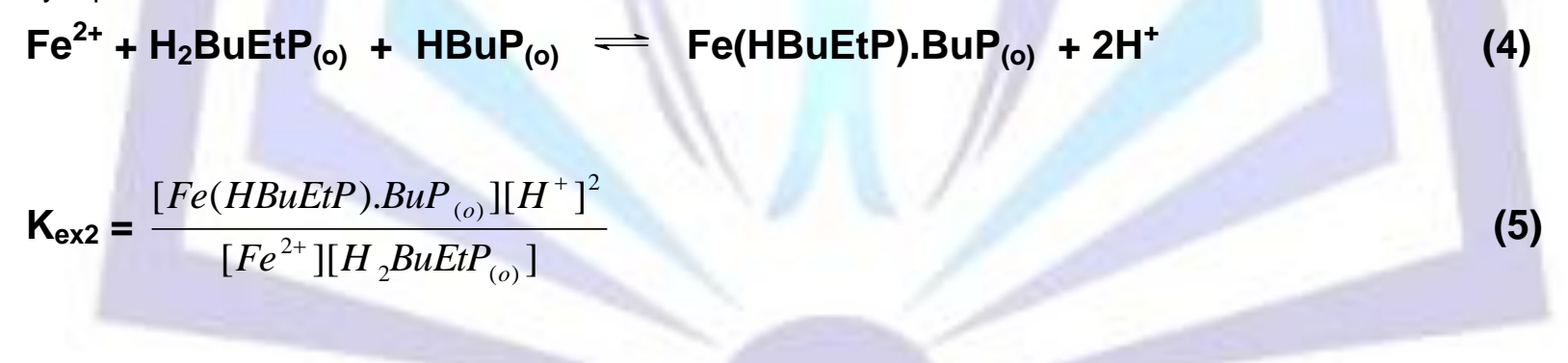

where $[\mathrm{HBuP}]$ is constant and incorporated in $\mathrm{K}_{\mathrm{ex} 2}$. The distribution ratio $D_{2}=\left[\mathrm{Fe}(\mathrm{HBuEtP}) \mathrm{BuP}_{(\mathrm{o})}\right] /\left[\mathrm{Fe}^{2+}\right]$, on substitution into equation (6) gives,

$$
\log D_{2}=\log K_{e x 2}+\log \left[H_{2} B u E t P\right]+2 p H
$$

The partition coefficient $\left[\mathrm{Fe}(\mathrm{HBuEtP}) \cdot \mathrm{BuP}_{(\mathrm{o})}\right] /[\mathrm{Fe}(\mathrm{HBuEtP}) \cdot \mathrm{BuP}]$ was determined from figure 3 to be equal to $1.68 \pm 0.18$. Log $\mathrm{K}_{\mathrm{ex} 2}$ was calculated from equation 6 to be $-13.27 \pm 0.54$ and the $\mathrm{pH}_{1 / 2}$, determined from figure 3 to be $7.13 \pm 0.10$. These results were not significantly different from those obtained with the ligand $\mathrm{H}_{2} \mathrm{BuEtP}$ alone even though they are slightly better; $\mathrm{K}_{\mathrm{D} 2 \mathrm{H} 2 \mathrm{BuEtP} / \mathrm{HBuP}}=1.68 \pm 0.18>\mathrm{K}_{\mathrm{D} 1 \mathrm{H} 2 \mathrm{BuEtP}}=1.5 \pm 0.16 ;$ Log $\mathrm{K}_{\text {ex2H2BuEtP/HBuP }}=-13.27 \pm 0.54>$ Log $\mathrm{K}_{\text {ex1 } 1 \text { 2BuEtP }}=$ $-13.45 \pm 0.2$. The $\mathrm{pH}_{1 / 2}$ was slightly reduced from $7.24 \pm 0.10$ in ligand $\mathrm{H}_{2} \mathrm{BuEtP}$ alone to $7.13 \pm 0.10$ in mixed ligands $\left(\mathrm{H}_{2} \mathrm{BuEtP} / \mathrm{HBuP}\right)$ organic phase. The $\mathrm{pH}$ range at which quantitative extraction occurred was still narrow $(7.25-8.25)$. However the optimal $\mathrm{pH}$ at which maximum extraction was achieved was slightly reduced from 8.25 in ligand $\mathrm{H}_{2} \mathrm{BuEtP}$ alone to 8.0 in mixed ligands $\left(\mathrm{H}_{2} \mathrm{BuEtP} / \mathrm{HbuP}\right)$ organic phase.

The distribution of $\mathrm{Fe}(\mathrm{II})$ in the mixed ligands organic phase was lower than those obtained for $\mathrm{U}(\mathrm{VI}), \mathrm{Pb}$ (II) and $\mathrm{Ni}(\mathrm{II})$ with the same mixed organic phase; $\log K_{D f e}=1.68 \pm 0.18<$ Log $K_{D u}=1.74 \pm 0.20<$ Log $K_{D P b}=1.82 \pm 0.22<$ Log $K_{\text {Dni }}=1.89$ \pm 0.02 . The combined results for the so far studied four metals with this same mixed ligands organic phase indicated that 
while quantitative extraction of $\mathrm{Fe}(\mathrm{II})$ occurred only above the neutral $\mathrm{pH}$ region $(7.75-8.00)$, the other three previously studied metals were quantitatively extraction over a wider range, stretching from the acidic $\mathrm{pH}$ region to the alkaline $\mathrm{pH}$ regions $\mathrm{Ni}(\mathrm{II})\left(6.0\right.$ - 9.0); $\mathrm{Pb}(\mathrm{II})(5.75-8.00)$ and $\mathrm{U}(\mathrm{VI})(3.75-7.25)^{8,9,10}$. This could be exploited in the separation of $\mathrm{Fe}(\mathrm{II})$ from $\mathrm{Ni}(\mathrm{II}), \mathrm{Pb}(\mathrm{II})$ and $\mathrm{U}(\mathrm{VI})$ in aqueous phases using the mixed ligands $\left(\mathrm{H}_{2} \mathrm{BuEtP} / \mathrm{HbuP}\right)$ organic phase.

Analysis of data showed that extraction involving a mixture of the ligands probably gave a protonated mixed ligand Fe(II) complex species. The suggested Iron complex species is shown in figure 8 having Fe-N bonds. The formation of the adduct complex $\mathrm{Fe}(\mathrm{HBuEtP}) \cdot \mathrm{BuP}_{(\mathrm{o})}$ resulted in increased distribution of $\mathrm{Fe}(\mathrm{II})$ into the organic phase due increased hydrophobicity and reduced polarity of the complex compared to the complex $\mathrm{Fe}(\mathrm{BuEtP})$ formed in the ligand $\mathrm{H}_{2} \mathrm{BuEtP}$ alone organic phase

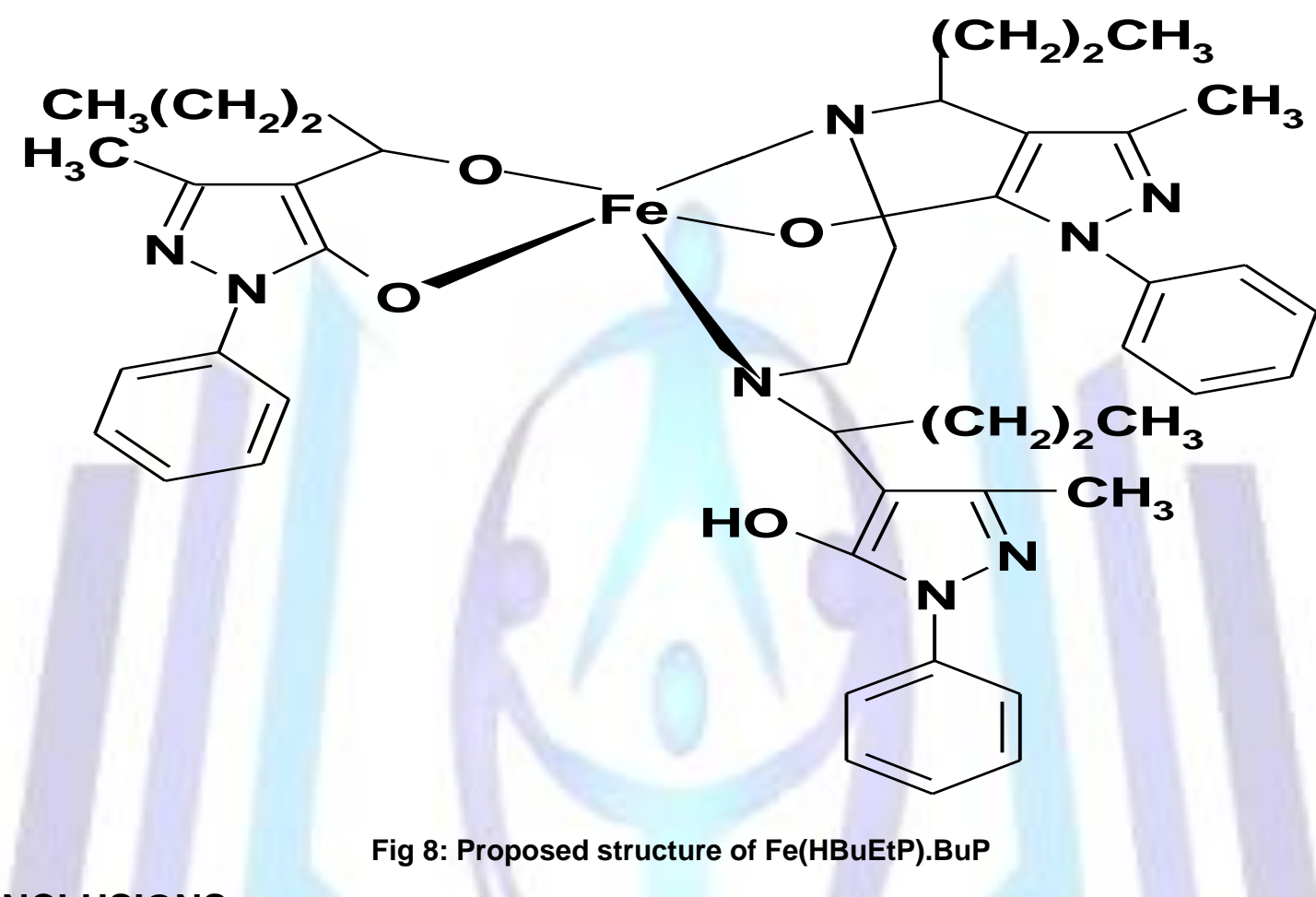

\section{CONCLUSIONS}

The ligand $\mathrm{H}_{2} \mathrm{BuEtP}$ has potentials for use as a colorimetric reagent for the analysis of Fe.

The ligand $\mathrm{H}_{2} \mathrm{BuEtP}$ can be used as an organic extractant for $\mathrm{Fe}(\mathrm{II})$ extraction from an aqueous solution, alone or in a mixed ligands organic system containing HBuP.

The optimal $\mathrm{pH}$ for extraction of $\mathrm{Fe}(\mathrm{II})$ with the ligand $\mathrm{H}_{2} \mathrm{BuEtP}$ alone and mixed ligands $\left(\mathrm{H}_{2} \mathrm{BuEtP}\right.$ and $\left.\mathrm{HBuP}\right)$ organic phase was 8.25 and 8.00 respectively.

Though the calculated extraction parameters showed that the ligand HBuP slightly improved the distribution of Fe(II) into organic phases, the synergistic effect of $\mathrm{HBuP}$ in the extraction of $\mathrm{Fe}(\mathrm{II})$ with $\mathrm{H}_{2} \mathrm{BuEtP}$ was not significant.

Slope analysis showed the extracted Fe complex species in both type of organic phases were $\mathrm{Fe}(\mathrm{BuEtP})$ 。 and $\mathrm{Fe}(\mathrm{HBuEtP}) \mathrm{BuP}_{0}$ respectively.

\section{ACKNOWLEDGEMENTS}

The authors wish to thank the Niger Delta University, Alexander von Humboldt Stiftung, Germany and Prof Karsten Gloe for research assistance to late BA Uzoukwu in the characterization of the Schiff base $\mathrm{H}_{2} \mathrm{BuEtP}$.

\section{REFERENCES}

[1] Liu, L., Jia, D. Z., Ji, Y. L., \& Yu, K. B. (2003). Synthesis, structure and photochromic properties of 4-acylpyrazolone derivants. J. Photochem. Photobiol, 154, 117.

[2] Liu, G., Liu, L., Jia, D., \& Yu, K. (2005). Synthesis, Structure and Photochromic Properties of 1-Phenyl-3-Methyl-4-(4Bromobenzal)-Pyrazolone-5 thiosemicarbazone. Structural Chemistry, 16(2), 135. 
[3] Yadav, S., Pandey O. P., \& Sengupta, S. K. (1995). Synthesis, physico-chemical and biological studies on oxovanadium(IV) derivatives of mercaptotriazoles. Transition Met. Chem., 20(2), 107.

[4] Magdy, A. H. Z., Farag, A. A., El-E., Salah, M. Y., Tarek, A. R. S., and Nader, M. B., (2007); 'Rapid and Efficient Synthesis of 4-Substituted Pyrazol-5-one under Microwave Irradiation in Solvent-Free Conditions', Archiv der Pharmazie, 340(11): pp. 591

[5] Okafor, E. C., and Uzoukwu, B. A. (1990)); 'Extraction of Fe(III) and U(VI) with 1-phenyl-3-methyl-4-acylpyrazolones 5 from aqueous solutions of different acids and complexing agents, separation of $\mathrm{Fe}(\mathrm{III})$ and $\mathrm{U}(\mathrm{VI})$ ' Radiochimica Acta, 51, pp 167 - 172

[6] Reyhaneh Rahnama and Mohammad Reza Jamali (2012), "Separation and Preconcentration of Trace Amounts of Manganese and Nickel from Natural Water Samples by a Diimine Derivative Schiff Base-Coated Silica-Gel Minicolumn," Journal of Chemistry, vol. 2013, Article ID 748106, 6 pages,

[7] Uzoukwu, B. A., Gloe, K., and Duddeck, H., (1998); 'N. N'-Ethylenebis(1-phenyl-3-methyl-4-acylpyrazoloneimine) derivatives: Synthesis and UV, IR, ${ }^{1} \mathrm{H}$ and ${ }^{13} \mathrm{C}$ NMR Spectral Studies', Indian Journal of Chemistry, 37B: pp. 1180 1183

[8] Godwin, J., Nwadire, C. F., and Uzoukwu, B. A. (2012); 'Extraction of Ni(II) lons into Chloroform solution of N, N'Ethylenebis(4-butanoyl-2,4-dihydro-5-methyl-2-phenyl-3H-pyrazol-3-oneimine) Schiff base', Eur. Chem. Bull.1(7): 269-273

[9] Godwin, J., and Uzoukwu, B. A. (2012a); 'Distribution of Pb (II) ions into chloroform solution of N,N-Ethylenebis(4Butanoyl-2,4-Dihydro-5-Methyl-2-Phenyl-3H-Pyrazol-3-Oneimine) as tris-complex species', Journal of Applied Chemistry (IOSRJAC) 1(3): pp 14-21

[10] Godwin, J., and Uzoukwu, B. A., (2012b); 'Distribution of U(VI) from aqueous solutions into chloroform solution of $\mathrm{N}, \mathrm{N}$ '-Ethylenebis(4-butanoyl-2,4-dihydro-5-methyl-2-phenyl-3H-pyrazol-3-oneimine) Schiff Base', International Journal of Chemistry; 4. (4): pp $105-116$

[11] Chukwu, U.J and Godwin, J (2013); Solvent Extraction Studies of Uranium (VI) from Aqueous Media into Chloroform Solution of $N, N^{\prime}$-ethylenebis(4-propionyl-2,4-dihydro-5-methyl-2-phenyl-3H-pyrazol-3-oneimine) American Chemical Science Journal 3(4): 479-488.

[12] Danopoulos, A. A., Tsoureas, N., Wright, A. J., and Light, E. M. (2004); 'N Heterocyclic Pincer Dicarbene Complexes of Iron(II): C-2 and C-5 Metalated Carbenes on the Same Metal Center' Organometallics, 23 (2): pp 166-168

[13] Mercs, L., Labat, G., Neels, A., Ehlers, A., and Albrecht, M., (2006); 'Piano-Stool Iron(II) Complexes as Probes for the Bonding of $\mathrm{N}$-Heterocyclic Carbenes: Indications for $\pi$-Acceptor Ability', Organometallics, 25 (23): pp 56485656

\section{Author' biography with Photo}

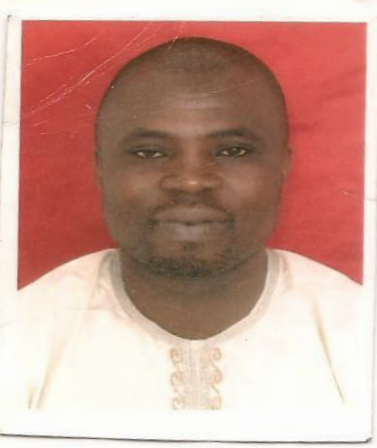

Dr Jackson Godwin was born in $27^{\text {th }}$ October, 1969 in Ekeni town in Southern ljaw Local Government area of Bayelsa State, Nigeria in Africa. I attended Holy Trinity Primary School, Aggrey Road, Port Harcourt between 1975 - 1981, Government Secondary School, Borikiri, Port Harcourt, Rivers State, Nigeria between $1981-1987$ and University of Port Harcourt, Rivers State, Nigeria between 1987 - 1991 where I obtained a Bachelor of Science Degree in Pure Chemistry.

I also have a Master of Science degree in Analytical Chemistry from Coventry University, United Kingdom in 2001 and a Doctor of Philosophy(Ph.D) in Analytical Chemistry from the University of Port Harcourt, Rivers State, Nigeria in 2014.

I have been working since 2000 as an academic staff with Niger Delta University, Wilberforce, Bayelsa State, Nigeria with research area and ten(10) publications in Environmental and Analytical Chemistry.

I am Married to Barrister (Mrs) Timiebi Godwin with two children, Miss Ayebatokoni Emmanuella Godwin(6 years) and Master Ebimobowei Jewel Godwin(5 years). 